Review

\title{
Incidence of Occult Lymph Node Metastasis in Primary Larynx Squamous Cell Carcinoma, by Subsite, T Classification and Neck Level: A Systematic Review
}

\author{
Alvaro Sanabria ${ }^{1,2}$, Jatin P. Shah ${ }^{3}$, Jesus E. Medina ${ }^{4}$, Kerry D. Olsen ${ }^{5}$, K. Thomas Robbins ${ }^{6}$, \\ Carl E. Silver ${ }^{7}$, Juan P. Rodrigo ${ }^{8,9,10}$ (D) Carlos Suárez ${ }^{11}$, Andrés Coca-Pelaz ${ }^{8,9,10}$, \\ Ashok R. Shaha ${ }^{3}$, Antti A. Mäkitie ${ }^{12}$, Alessandra Rinaldo ${ }^{13}$, Remco de Bree ${ }^{14}(\mathbb{D}$, \\ Primož Strojan ${ }^{15}\left(\mathbb{D}\right.$, Marc Hamoir ${ }^{16}{ }^{(D)}$, Robert P. Takes ${ }^{17}$, Elisabeth V. Sjögren ${ }^{18}$, \\ Trinitia Cannon ${ }^{19}$, Luiz P. Kowalski ${ }^{20,21}$ (D) and Alfio Ferlito $22, *,+$
}

1 Department of Surgery, School of Medicine, Universidad de Antioquia/Hospital Universitario San Vicente Fundación, Medellín 050010, Colombia; alvarosanabria@gmail.com

2 CEXCA Centro de Excelencia en Enfermedades de Cabeza y Cuello, Medellín 050021, Colombia

3 Department of Surgery, Memorial Sloan Kettering Cancer Center, New York, NY 10065, USA; shahj@mskcc.org (J.P.S.); shahaa@mskcc.org (A.R.S.)

4 Department of Otorhinolaryngology, The University of Oklahoma Health Sciences Center, Oklahoma City, OK 73117, USA; Jesus-Medina@ouhsc.edu

5 Department of Otorhinolaryngology, Mayo Clinic, Rochester, MN 55902, USA; olsen.kerry@mayo.edu

6 Department of Otolaryngology-Head and Neck Surgery, Southern Illinois University School of Medicine, Springfield, IL 32952, USA; kthomasrobbins@gmail.com

7 Department of Surgery, University of Arizona College of Medicine, Phoenix, AZ 85259, USA; csilver@cox.net

8 Department of Otolaryngology, Hospital Universitario Central de Asturias-ISPA, 33011 Oviedo, Spain; jprodrigo@uniovi.es (J.P.R.); acocapelaz@yahoo.es (A.C.-P.)

9 University of Oviedo-IUOPA, 33011 Oviedo, Spain

10 Head and Neck Cancer Unit, CIBERONC, 28029 Madrid, Spain

11 Instituto de Investigación Sanitaria del Principado de Asturias, 33011 Oviedo, Spain; csuareznieto@gmail.com

12 Department of Otorhinolaryngology-Head and Neck Surgery, University of Helsinki and Helsinki University Hospital, FI-00029 HUS Helsinki, Finland; Antti.Makitie@hus.fi

13 University of Udine School of Medicine, 33100 Udine, Italy; alessandra.rinaldo@uniud.it

14 Department of Head and Neck Surgical Oncology, University Medical Center Utrecht, 3584CX Utrecht, The Netherlands; R.deBree@umcutrecht.nl

15 Department of Radiation Oncology, Institute of Oncology, SI-1000 Ljubljana, Slovenia; pstrojan@onko-i.si

16 Department of Head and Neck Surgery, UC Louvain, St Luc University Hospital and King Albert II Cancer Institute, 1200 Brussels, Belgium; marc.hamoir@uclouvain.be

17 Department of Otolaryngology-Head and Neck Surgery, Radboud University Medical Center, 6500HB Nijmegen, The Netherlands; Robert.Takes@radboudumc.nl

18 Department of Otolaryngology-Head and Neck Surgery, Leiden University Medical Centre, 2300 RC Leiden, The Netherlands; evsjogren@lumc.nl

19 Department of Head and Neck Surgery and Communication Sciences, Duke University Health System, Durham, NC 27609, USA; Trinitia.Cannon@duke.edu

20 Department of Otorhinolaryngology-Head and Neck Surgery, A.C. Camargo Cancer Center, 01509-900 São Paulo, Brazil; lp_kowalski@uol.com.br

21 Department of Head and Neck Surgery, University of São Paulo Medical School, 05402-000 São Paulo, Brazil

22 International Head and Neck Scientific Group, 35100 Padua, Italy

* Correspondence: alfio.ferlito@uniud.it

$+\quad$ This article was written by members and invitees of the International Head and Neck Scientific Group (www.IHNSG.com). 
Abstract: Background: Larynx cancer is a common site for tumors of the upper aerodigestive tract. In cases with a clinically negative neck, the indications for an elective neck treatment are still debated. The objective is to define the prevalence of occult metastasis based on the subsite of the primary tumor, T classification and neck node levels involved. Methods: All studies included provided the rate of occult metastases in cN0 larynx squamous cell carcinoma patients. The main outcome was the incidence of occult metastasis. The pooled incidence was calculated with random effects analysis. Results: 36 studies with 3803 patients fulfilled the criteria. The incidence of lymph node metastases for supraglottic and glottic tumors was 19.9\% (95\% CI 16.4-23.4) and 8.0\% (95\% CI 2.7-13.3), respectively. The incidence of occult metastasis for level I, level IV and level V was $2.4 \%$ (95\% CI 0-6.1\%), $2.0 \%$ (95\% CI 0.9-3.1) and $0.4 \%$ (95\% CI 0-1.0\%), respectively. For all tumors, the incidence for sublevel IIB was $0.5 \%$ (95\% CI 0-1.3). Conclusions: The incidence of occult lymph node metastasis is higher in supraglottic and T3-4 tumors. Level I and V and sublevel IIB should not be routinely included in the elective neck treatment of cNO laryngeal cancer and, in addition, level IV should not be routinely included in cases of supraglottic tumors.

Keywords: larynx neoplasm; neck dissection; systematic review; glottis; supraglottis

\section{Introduction}

The larynx is the site for the second most common cancer of the upper aerodigestive tract. While in some countries the incidence of larynx cancer has risen in the last forty years, due to smoking and drinking, in the USA and Northern Europe it has decreased dramatically [1,2].

Adequate treatment of larynx cancer centers around local control of the primary tumor, as well as control of clinical or occult neck lymph node metastasis. If the patient presents with positive lymph nodes in the lateral compartment of the neck and the planned treatment option for the primary tumor is surgery, there is no doubt that the preferred treatment is a neck dissection most likely followed by radiotherapy alone or in combination with chemotherapy [3]. The lymph node levels to be included in the dissection and the radiotherapy fields depend on the level of positive nodes found by palpation and radiological examination, as well as the laryngeal subsite(s) involved by cancer and $\mathrm{T}$ classification of the tumor. However, there still is an ongoing discussion about which neck levels should be included [4-7]. On the other hand, in cases with a clinically negative neck, the indications for and the extent of an elective neck dissection or elective neck irradiation are still debated vigorously in the literature, the scientific community and multidisciplinary tumor board meetings. Although, depending mainly on the subsite and $\mathrm{T}$ classification of the primary tumor, the final decision making should take into account the expected survival advantages as a result of elective treatment of the neck, as well as the functional and esthetic morbidity that may result from it.

The rationale to offer elective treatment of the neck in patients with larynx cancer is the potential presence of occult lymph node metastases, which can result in recurrence after successful initial treatment of the primary tumor. However, it has been reported that the results with elective neck dissection or irradiation are not superior to those of "watchful" surveillance without neck surgery or radiotherapy in early stage laryngeal cancer [8]. It is also known that the social and psychological make-up of some patients with larynx cancer is such that when they present with a recurrence in the neck after a "watchful" waiting policy, it is often at an advanced stage and salvage treatment may not be successful. Consequently, many clinicians prefer performing an elective neck dissection/irradiation in spite of the fact that tumor recurrence owing to adverse biological characteristics of the cancer may develop even after a neck dissection and radiation therapy. Therefore, the procedure may not offer any advantage in survival and the morbidity associated with an elective neck dissection may decrease the quality of life $[9,10]$. 
Central to the discussion of elective treatment of the neck is the ability to predict correctly the likelihood of occult metastasis in a given patient and the neck node levels that are at highest risk of containing metastases, which, therefore, need to be removed or irradiated electively. Unfortunately, neither modern imaging techniques nor molecular marker analysis of the primary tumor, nor sentinel lymph node biopsy $[5,11]$, are generally felt to be accurate enough to be considered the standard of care.

The objective of this review is to assess the available literature in order to define the prevalence of occult metastasis in larynx cancer based on three key factors: subsite of the primary tumor (glottic or supraglottic), T classification and neck node levels involved. Information about bilateral metastasis was not included. The data are intended to provide a rationale for the indications and extent of elective neck treatment based on the specific factors analyzed.

\section{Results}

The primary search found 2025 studies. Only 36 studies with 3803 patients fulfilled the inclusion criteria for the review and are presented in Table 1 [10,12-46]. Most exclusions were based on indeterminate outcomes or because the primary treatment was with radiotherapy/chemoradiotherapy. Ten studies were excluded because $\mathrm{cN}+$ patients were also included in the sample [47-56] and one because it was not possible to get full text [57]. Data from Deganello et al. [10], Pinilla et al. [23] and Zhang et al. [31] reported individual data about subsites and were divided in order to include their cases in different categories [glottic, supraglottic or larynx, not otherwise specified (LNOS)] (Table 1). Three studies from the same center had overlapping patients but they were analyzed independently because the numbers, outcomes and objectives were different [32,33,35].

All the studies were case series, except the case control study by Djordjevic et al. [45]. Eight studies were prospective $[20,25,27,29,36,39,42,45]$; fifteen studies analyzed the larynx without specification of occult metastasis by subsite $[10,13,15,20,24-27,29,34,37,39,40,43,46]$; nineteen analyzed supraglottic tumors [10,12,14,16,18,19,22,23,28,30-33,35,36,38,42,44,45]; and six, glottic tumors [10,17,21,23,31,41]. Katilmis et al. included a small number of hypopharynx tumors (13/213) [34].

\subsection{Description of Patients Included in the Studies}

In total, 2226 patients had supraglottic tumors, 412 patients had transglottic tumors and 776 had glottic tumors with or without extension to other sites, such as the subglottis or supraglottis. Two studies (389 patients) did not report distribution by subsite [24,26]. In total, 1643 patients were classified as T1-2 and 1785 as T3-4. In two studies (366 patients) it was impossible to obtain data on clinical stage $[24,39]$. Regarding treatment, 852 patients underwent partial laryngectomy while 675 had total laryngectomy. Thirteen studies did not report the surgical procedure done for the primary tumor $[10,24,25,27,28,31-33,37,39,40,43,45]$. 
Table 1. Characteristics of the studies included in the systematic review.

\begin{tabular}{|c|c|c|c|c|c|c|c|c|c|c|c|c|c|c|c|c|c|c|c|c|c|c|c|c|c|}
\hline \multirow{2}{*}{ Author } & \multirow{2}{*}{ Year } & \multirow{2}{*}{ Country } & \multirow{2}{*}{$\begin{array}{l}\text { Time } \\
\text { Period }\end{array}$} & \multirow{2}{*}{$\begin{array}{l}\text { Study } \\
\text { Type }\end{array}$} & \multirow{2}{*}{ Design } & \multirow{2}{*}{$N$} & \multirow{2}{*}{ Subsite } & \multirow{2}{*}{ cN+ } & \multirow{2}{*}{ T1-2/T3-4 } & \multirow{2}{*}{$\begin{array}{l}\text { Partial/Total } \\
\text { Laryngectomy }\end{array}$} & \multirow{2}{*}{$\begin{array}{l}\text { \% Occult } \\
\text { Metastasis }\end{array}$} & \multicolumn{6}{|c|}{ Neck Level } & \multicolumn{8}{|c|}{ T Classification } \\
\hline & & & & & & & & & & & & I & II & III & IV & $\mathrm{v}$ & IIB & T1 & T1t & T2 & T2t & T3 & T3t & $\mathrm{T} 4$ & $\mathrm{~T} 4 \mathrm{t}$ \\
\hline $\begin{array}{l}\text { Levendag and } \\
\text { Vikram [12] }\end{array}$ & 1987 & USA & 1965-1979 & CS & $\mathrm{R}$ & 79 & $\mathrm{~s}$ & & $79 / 0$ & $31 / 48$ & 10 & & & & & & & & & & & & & & \\
\hline Candela et al. [13] & 1990 & USA & 1965-1986 & CS & $\mathrm{R}$ & 78 & LNOS & & $36 / 42$ & NR & 29 & 4 & 15 & 16 & 7 & 2 & & & & & & & & & \\
\hline $\begin{array}{l}\text { Ramadan and } \\
\text { Allen [14] }\end{array}$ & 1993 & USA & 1975-1986 & CS & $\mathrm{R}$ & 63 & $\mathrm{~s}$ & & $16 / 49$ & NR & 7 & & & & & & & & & 1 & 4 & 3 & 8 & 3 & 9 \\
\hline Kligerman et al. [15] & 1995 & Brazil & 1981-1989 & CS & $\mathrm{R}$ & 76 & LNOS & & $0 / 76$ & $1 / 75$ & 23 & & & & & & & & & & & 16 & 56 & 7 & 20 \\
\hline Petrovic et al. [16] & 1997 & Yugoslavia & 1976-1990 & CS & $\mathrm{R}$ & 161 & $\mathrm{~s}$ & & $90 / 71$ & NR & 29 & & & & & & & 4 & 22 & 9 & 68 & 6 & 45 & 10 & 26 \\
\hline Yang et al. [17] & 1998 & USA & 1984-1994 & CS & $\mathrm{R}$ & 92 & G & & $71 / 21$ & NR & 4 & & & & & & & 0 & 0 & 0 & 0 & 3 & 14 & 1 & 7 \\
\hline $\begin{array}{l}\text { Güney and } \\
\text { Yigitbasi [18] }\end{array}$ & 1999 & Turkey & 1991-1996 & CS & $\mathrm{R}$ & 39 & $\mathrm{~s}$ & & $39 / 0$ & NR & 9 & & & & & & & & & & & & & & \\
\hline Tu [19] & 1999 & China & 1976-1990 & CS & $\mathrm{R}$ & 155 & $\mathrm{~S}$ & & $51 / 91$ & $128 / 34$ & 13 & & & & & & & & & & & & & & \\
\hline León et al. [20] & 2001 & Spain & 1991-1997 & CS & $\mathrm{P}$ & 79 & LNOS & & $23 / 56$ & NR & 23 & & & & 2 & 0 & & & & & & & & & \\
\hline Elo et al. [21] & 2002 & Hungary & 1989-1999 & CS & $\mathrm{R}$ & 206 & G & & $133 / 73$ & $133 / 73$ & 24 & & & & & & & 0 & 61 & 6 & 72 & 9 & 54 & 9 & 19 \\
\hline Amoros et al. [22] & 2003 & Spain & 1977-1999 & CS & $\mathrm{R}$ & 164 & $\mathrm{~S}$ & & $103 / 61$ & NR & 40 & & & & & & & & & & & & & & \\
\hline \multirow{2}{*}{ Pinilla et al. [23] } & \multirow{2}{*}{2003} & \multirow{2}{*}{ Spain } & \multirow{2}{*}{ 1983-1993 } & \multirow{2}{*}{ CS } & \multirow{2}{*}{$\begin{array}{l}\mathrm{R} \\
\mathrm{R}\end{array}$} & 124 & $\mathrm{~S}$ & & $56 / 68$ & NR & 34 & & & & & & & 0 & 6 & 9 & 50 & 9 & 42 & 16 & 26 \\
\hline & & & & & & 66 & G & & $44 / 22$ & NR & 9 & & & & & & & 0 & 1 & 1 & 43 & 6 & 18 & 2 & 4 \\
\hline Spriano et al. [24] & 2003 & Italy & 1980-1997 & CS & $\mathrm{R}$ & 346 & LNOS & & NR & NR & 59 & & 56 & 33 & 5 & 10 & & & & & & & & & \\
\hline Coskun et al. [25] & 2004 & Turkey & 1999-2002 & CS & $\mathrm{P}$ & 71 & LNOS & & $12 / 59$ & NR & 14 & & & & 0 & & 0 & & & & & & & & \\
\hline Khafif et al. [26] & 2004 & $\begin{array}{l}\text { Israel } \\
\text { USA }\end{array}$ & & CS & $\mathrm{R}$ & 43 & LNOS & & $0 / 43$ & $0 / 100$ & 9 & & & & 1 & & & & & & & & & & \\
\hline Elsheikh et al. [27] & 2006 & Egypt & $2001-2004$ & CS & $\mathrm{P}$ & 31 & LNOS & & $19 / 12$ & NR & 6 & & 2 & 3 & 1 & & 0 & & & & & & & & \\
\hline Fiorella et al. [28] & 2006 & Italy & & CS & $\mathrm{R}$ & 106 & S & & $50 / 56$ & NR & 29 & & & & & & & & & $\begin{array}{c}0, \\
16\end{array}$ & & 19 & 53 & 2 & 3 \\
\hline Lim et al. [29] & 2006 & Korea & $1997-2002$ & CS & $\mathrm{P}$ & 73 & LNOS & & $33 / 40$ & $16 / 53$ & 21 & & 12 & 9 & 5 & & & 0 & 3 & 1 & 30 & 2 & 34 & 2 & 6 \\
\hline Rodrigo et al. [30] & 2006 & Spain & $1975-1998$ & CS & $\mathrm{R}$ & 108 & $\mathrm{~s}$ & & $108 / 0$ & $108 / 0$ & 16 & & & & & & & & & & & & & & \\
\hline \multirow{2}{*}{ Zhang et al. [31] } & \multirow{2}{*}{2006} & China & 1997-2002 & CS & $\mathrm{R}$ & 72 & $\mathrm{~S}$ & & $36 / 36$ & NR & 15 & & & & & & & 1 & 12 & 6 & 24 & 7 & 30 & 1 & 6 \\
\hline & & & & & & 38 & G & & $13 / 25$ & NR & 7 & & & & & & & & & 1 & 13 & 2 & 14 & 4 & 11 \\
\hline Cağli et al. [33] & 2007 & Turkey & 1998-2006 & CS & $\mathrm{R}$ & 72 & $\mathrm{~s}$ & & $12 / 60$ & NR & 16 & & 16 & 7 & 1 & & & & & 1 & 12 & 10 & 44 & 5 & 16 \\
\hline Cağli et al. [32] & 2007 & Turkey & & CS & $\mathrm{R}$ & 58 & $\mathrm{~s}$ & & $22 / 36$ & NR & 14 & & 11 & 7 & 1 & & & & & 3 & 22 & 7 & 28 & 4 & 8 \\
\hline Katilmis et al. [34] & 2007 & Turkey & 1998-2003 & CS & $\mathrm{R}$ & 224 & LNOS & & $79 / 145$ & $60 / 164$ & & & 24 & 12 & 7 & 0 & & & & & & & & & \\
\hline Yüce et al. [35] & 2009 & Turkey & 1991-2005 & $\mathrm{CC}$ & $\mathrm{R}$ & 71 & $\mathrm{~s}$ & & $71 / 0$ & $67 / 4$ & 9 & & & & & & & & & & & & & & \\
\hline Lawson et al. [36] & 2010 & Belgium & 2001-2004 & CS & $P$ & 29 & $\mathrm{~s}$ & & $25 / 6$ & $29 / 0$ & 14 & & & & & & & & & & & & & & \\
\hline
\end{tabular}


Table 1. Cont.

\begin{tabular}{|c|c|c|c|c|c|c|c|c|c|c|c|c|c|c|c|c|c|c|c|c|c|c|c|c|c|}
\hline \multirow{2}{*}{ Author } & \multirow{2}{*}{ Year } & \multirow{2}{*}{ Country } & \multirow{2}{*}{$\begin{array}{c}\text { Time } \\
\text { Period }\end{array}$} & \multirow{2}{*}{$\begin{array}{l}\text { Study } \\
\text { Type }\end{array}$} & \multirow{2}{*}{ Design } & \multirow{2}{*}{$N$} & \multirow{2}{*}{ Subsite } & \multirow{2}{*}{$\mathrm{cN}+$} & \multirow{2}{*}{ T1-2/T3-4 } & \multirow{2}{*}{$\begin{array}{l}\text { Partial/Total } \\
\text { Laryngectomy }\end{array}$} & \multirow{2}{*}{$\begin{array}{c}\% \text { Occult } \\
\text { Metastasis }\end{array}$} & \multicolumn{6}{|c|}{ Neck Level } & \multicolumn{8}{|c|}{ T Classification } \\
\hline & & & & & & & & & & & & I & II & III & IV & $\mathrm{V}$ & IIB & T1 & T1t & $\mathrm{T} 2$ & T2t & T3 & T3t & $\mathrm{T} 4$ & $\mathrm{~T} 4 \mathrm{t}$ \\
\hline Mnejja et al. [37] & 2010 & Tunisia & 1990-2007 & CS & $\mathrm{R}$ & 164 & LNOS & & $36 / 128$ & NR & 32 & & & & 9 & & 8 & & & & & & & & \\
\hline Csanady et al. [38] & 2011 & Hungary & 1987-2006 & CS & $\mathrm{R}$ & 55 & $\mathrm{~s}$ & & $55 / 0$ & $55 / 0$ & 15 & & & & & & & & & & & & & & \\
\hline \multirow{2}{*}{ Deganello et al. [10] } & \multirow{2}{*}{2011} & \multirow{2}{*}{ Italy } & \multirow{2}{*}{ 2000-2004 } & \multirow{2}{*}{ CS } & \multirow{2}{*}{$\mathrm{R}$} & 96 & LNOS & & $55 / 41$ & $82 / 14$ & 12 & 1 & 10 & 3 & 2 & 0 & & & & & & & & & \\
\hline & & & & & & 57 & $\mathrm{~S}$ & & $35 / 22$ & NR & 9 & & & & & & & & & 4 & 24 & 3 & 10 & 2 & 12 \\
\hline Deganello et al. [10] & 2011 & Italy & $2000-2004$ & CS & $\mathrm{R}$ & 39 & G & & $20 / 19$ & NR & 3 & & & & & & & & & & & 1 & 17 & 2 & 2 \\
\hline Chone et al. [39] & 2012 & Brazil & 2007-2011 & CS & $\mathrm{P}$ & 20 & LNOS & & NR & NR & NR & & & & 0 & & & & & & & & & & \\
\hline Xu et al. [40] & 2012 & China & 1996-2009 & CS & $\mathrm{R}$ & 126 & LNOS & & $15 / 111$ & NR & 41 & & & & & & & & & & & & & & \\
\hline Erdag et al. [41] & 2013 & Turkey & 1996-2009 & CS & $\mathrm{R}$ & 24 & G & & $24 / 0$ & $24 / 0$ & 0 & & & & & & & & & & & & & & \\
\hline Jia et al. [42] & 2013 & China & 2002-2010 & CS & $\mathrm{P}$ & 68 & $\mathrm{~S}$ & & $36 / 32$ & $52 / 16$ & 21 & & & & & & 0 & & & 9 & 36 & 10 & 27 & 2 & 5 \\
\hline $\begin{array}{l}\text { Furtado de Araújo } \\
\text { Neto et al. [43] }\end{array}$ & 2014 & Brazil & 2007-2012 & CS & $\mathrm{R}$ & 77 & LNOS & & 0/77 & NR & 12 & & & & 3 & & & & & & & & & & \\
\hline Ma et al. [44] & 2014 & China & $2002-2013$ & CS & $\mathrm{R}$ & 121 & $\mathrm{~s}$ & & $39 / 82$ & $66 / 55$ & 34 & & 22 & 21 & 4 & & 2 & & & 6 & 39 & 13 & 40 & 15 & 42 \\
\hline Djordjevic et al. [45] & 2016 & Serbia & 1996-2005 & $\mathrm{CC}$ & $\mathrm{R}$ & 193 & $\mathrm{~s}$ & & $107 / 86$ & NR & 35 & & 31 & 8 & 1 & & & & & & & & & & \\
\hline Tsushima et al. [46] & 2019 & Japan & 1998-2014 & CS & $\mathrm{R}$ & 39 & LNOS & & $0 / 39$ & $0 / 39$ & 14 & & 4 & 3 & 0 & & 0 & & & & & & & & \\
\hline
\end{tabular}

CS: case series; CC: case control; G: glottis; LNOS: larynx, not otherwise specified; NR: not reported; P: prospective; R: retrospective; S: supraglottis. 


\subsection{Methodological Quality}

The methodological quality of the included studies was moderate to good. The mean score was $8.3 \pm 1.4$ over a maximum score of 10 . Only $4 / 36(11 \%)$ of the studies scored lower than 7 . The item with the lowest score was "Did the case series have complete inclusion of participants?", where 21/36 (58\%) studies had a no/unclear result, followed by "Did the case series have consecutive inclusion of participants?", where 14/36 (39\%) had a no/unclear result (Figure 1).

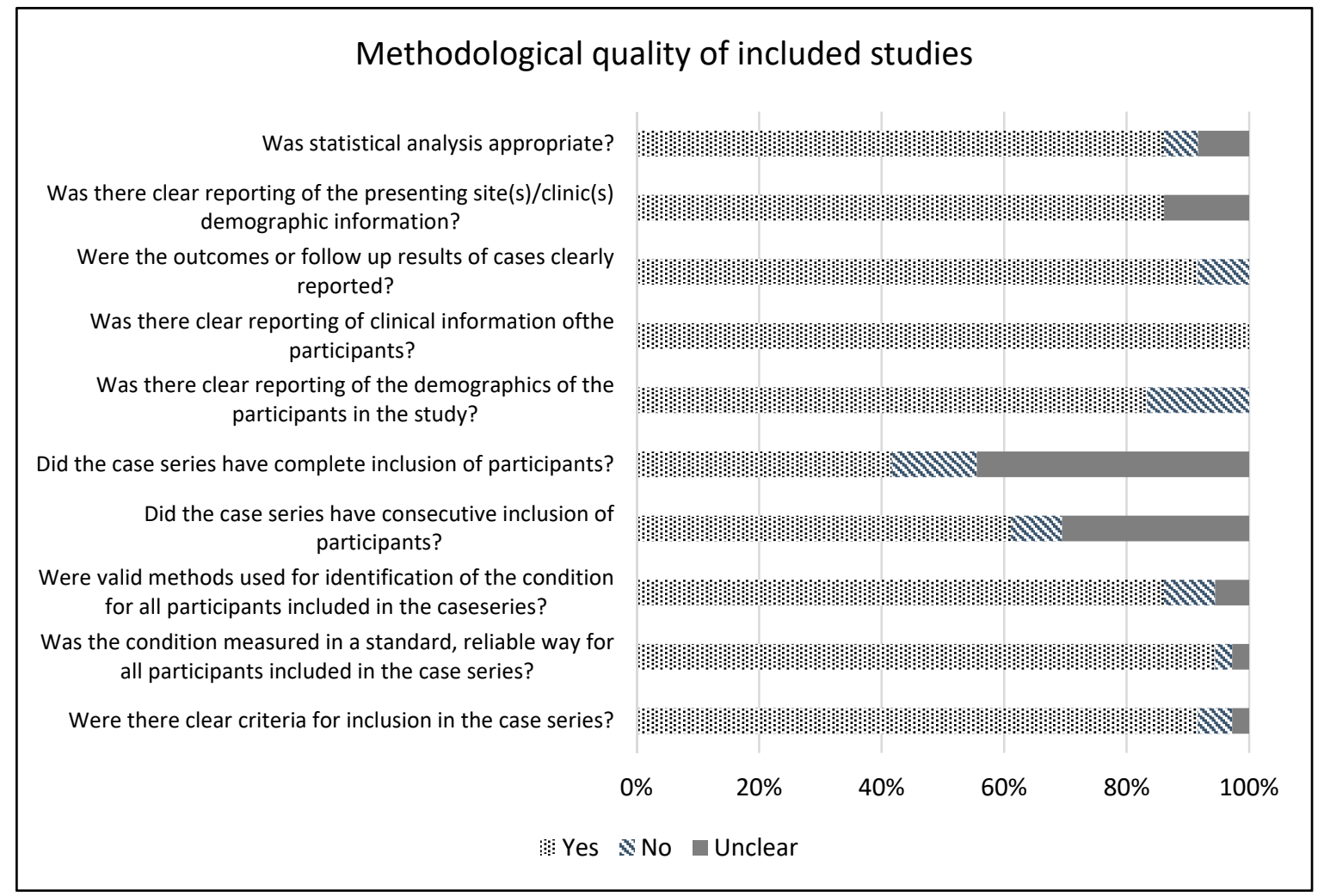

Figure 1. Methodological quality of the included studies.

\subsection{Rate of Occult Metastasis}

All studies, except two [34,39], reported an overall rate of occult metastasis of 18.7\% (711/3803 patients). The pooled incidence was not calculated due to the expected clinical and statistical heterogeneity by subsites.

\subsubsection{Supraglottic Tumors}

Nineteen studies specified supraglottic tumors $[10,12,14,16,18,19,22,23,28,30-33,35,36,38,42,44,45]$. The calculated pooled incidence of LN metastases was 19.9\% (95\% CI 16.4-23.4, I2 $=65 \%$ ) (Figure S1). More than half (56.1\%) of the patients were classified as having a T1-2 tumor. The rate of occult metastases varied widely among the reported series. Lawson et al. [36] showed a high risk of occult metastasis of 48.2\%. Tu et al. [19], Ramadan and Allen [14] and Levendag and Vikram [12] showed rates of occult metastasis lower than $12 \%$. No clear explanation for statistical heterogeneity was found. A subgroup analysis with studies that included $>75 \%$ of $\mathrm{T} 1-2$ tumors $[12,18,30,35,36,38]$ was done and the pooled incidence was $18.4 \%$ (95\% CI 11.8-25.0, I2 = 54\%) (Figure S2).

\subsubsection{Glottic Tumors}

From the six studies that specified glottic tumors $[10,17,21,23,31,41]$ approximately two thirds $(65.6 \%)$ were classified as T1-2. They reported a pooled incidence for occult metastasis of $8.0 \%(95 \% \mathrm{CI}$ 
2.7-13.3, I2 = 81\%) (Figure S1). Among these studies, Erdag et al. [41] reported an incidence for occult metastases of $0 \%$, thus explaining the high statistical heterogeneity in this analysis. Figure 2 shows the comparison of occult lymph node metastasis by subsite.

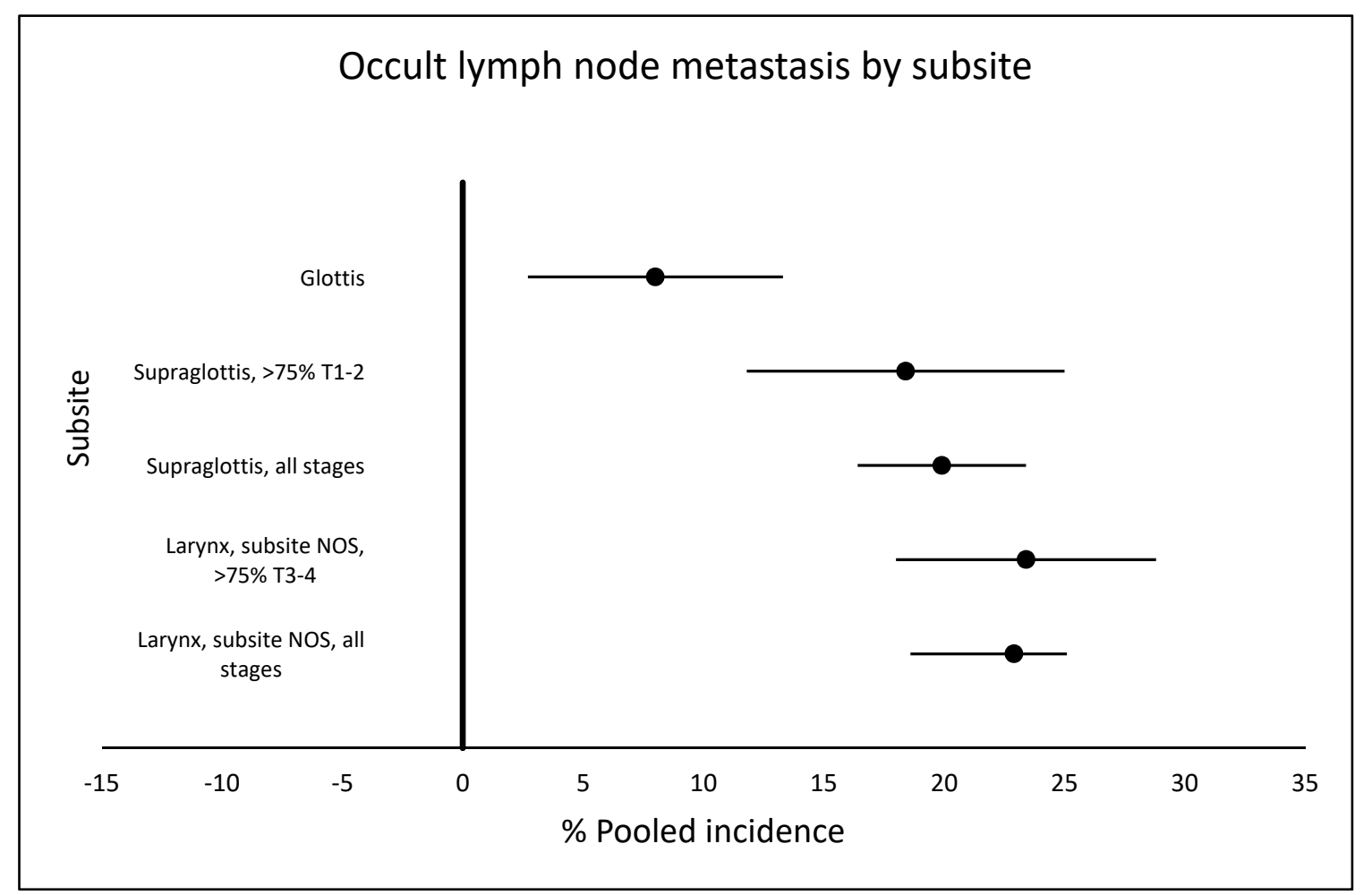

Figure 2. Comparison of pooled incidences of occult lymph node metastasis by subsite in cN0 larynx cancer. NOS: not otherwise specified

\subsubsection{Larynx Tumors without Specification of Subsite}

Fifteen studies assessed larynx tumors without specifying the outcomes by subsite (NOS) [10,13, $15,20,24-27,29,34,37,39,40,43,46]$. Patients had tumors classified as supraglottic in $26.1 \%$, transglottic in $24.8 \%$ and glottic/other site in $21.0 \%$ of the cases. One fifth (19.6\%) were classified as T1-2 and more than half $(54.0 \%)$ as T3-4. There was no information on subsite in $28.1 \%$ or stage in $26.4 \%$ of patients. These studies reported a pooled incidence of occult metastasis of $22.9 \%(95 \%$ CI 18.6-25.1, I2 = 58\%) (Figure S1). A subgroup analysis of studies that included $>75 \%$ of T3-4 tumors $[15,25,26,37,40,43,46]$ was done, and the pooled incidence was $23.4 \%(95 \%$ CI 18.0-28.8, I2 = 44\%) (Figure S3).

\subsection{Occult Metastasis by Lymph Node Level}

The presence of occult lymph node metastasis at level I was reported in only two studies [10,13], but in both there was no information about involvement of sublevels IA or IB. Level II involvement was reported in eleven studies [10,13,24,27,29,32-34,44-46], level III in eleven studies $[10,13,24,27,29$, 32-34,44-46], level IV in seventeen studies [10,13,20,24-27,29,32-34,37,39,43-46] and level V in five studies $[10,13,20,24,34]$. Figures S4, S5 and Table S1 shows data about the studies and pooled incidence and Figure 3 shows the comparison of occult lymph node metastasis by level. 


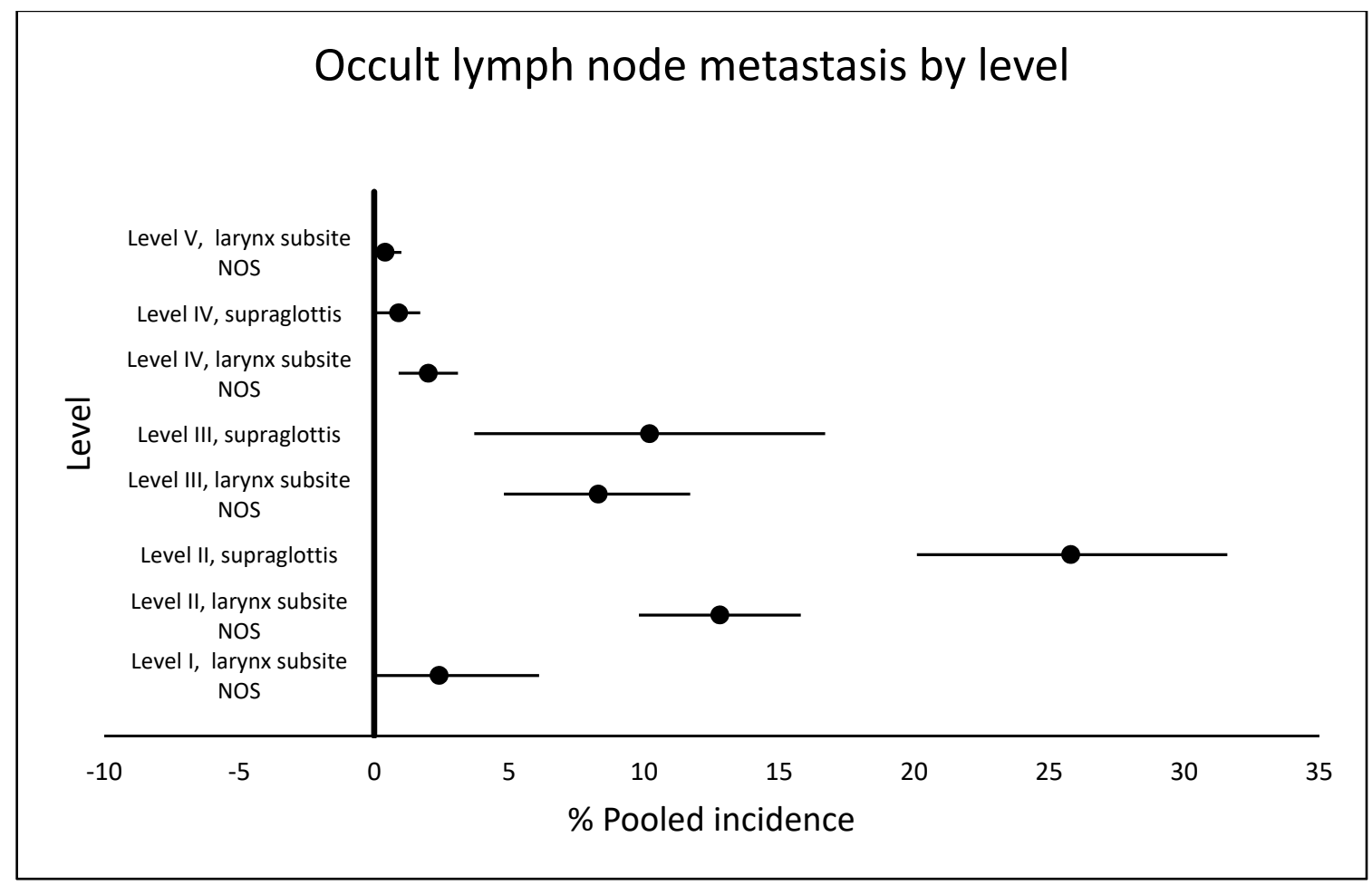

Figure 3. Comparison of pooled incidences of occult lymph node metastasis by level in cN0 larynx cancer. NOS: not otherwise specified

The studies of Candela et al. [13] and Djordjevic et al. [45] explain the statistical heterogeneity for the level III analysis and the study of Spriano et al. [24] explains the statistical heterogeneity for the level $\mathrm{V}$ analysis.

\subsection{Occult Metastasis by T Classification}

Five studies reported data on the T1 stage [16,21,23,29,31]. Five of 105 patients $(4.8 \%)$ had occult metastasis. It was impossible to calculate a pooled incidence as Elo et al. [21], Pinilla et al. [23] and Lim et al. [29] did not observe any event in this category.

Twelve studies reported data on the T2 stage $[10,14,16,21,23,28,29,31-33,42,44]$. For the subgroup with glottic tumors $[21,23,31]$, the pooled incidence was $4.7 \%(95 \% \mathrm{CI} 0.5-8.8$, I2 $=13 \%)$. In the subgroup of supraglottic tumors $[10,14,16,23,28,31-33,42,44]$, the pooled incidence was $16.5 \%(95 \% \mathrm{CI}$ $14.8-18.3, \mathrm{I} 2=0 \%$ ) (Figures S6 and S7).

Fourteen studies reported data on the T3 stage $[10,14-17,21,23,28,29,31-33,42,44]$. For the subgroup of glottic tumors $[10,17,21,23,31]$, the pooled incidence was $14.4 \%(95 \%$ CI $6.9-21.8, \mathrm{I} 2=11 \%)$. In the subgroup of supraglottic tumors $[10,14,16,23,28,31-33,42,44]$, the pooled incidence was $23.8 \%$ ( $95 \%$ CI $18.6-28.9$, I2 $=0 \%$ ). For larynx subsite NOS, two studies $[15,29]$ reported a pooled incidence of $16.5 \%$ (95\% CI 0-38.6) (Figures S6 and S7)

Fourteen studies reported data on the T4 stage $[10,14-17,21,23,28,29,31-33,42,44]$. For the subgroup of glottic tumors $[10,17,21,23,31]$, the pooled incidence was $32.7 \%(95 \%$ CI $16.6-48.8$, I $2=0)$. In the subgroup of supraglottic tumors, the pooled incidence was $34.0 \%(95 \%$ CI $26.1-41.9$, I2 $=0)$. In the larynx subsite NOS, two studies [15,29] reported a pooled incidence of 34.6\% (95\% CI 11.9-57.2) (Figures S6 and S7). Figure 4 shows the comparison of occult lymph node metastasis by T classification. 


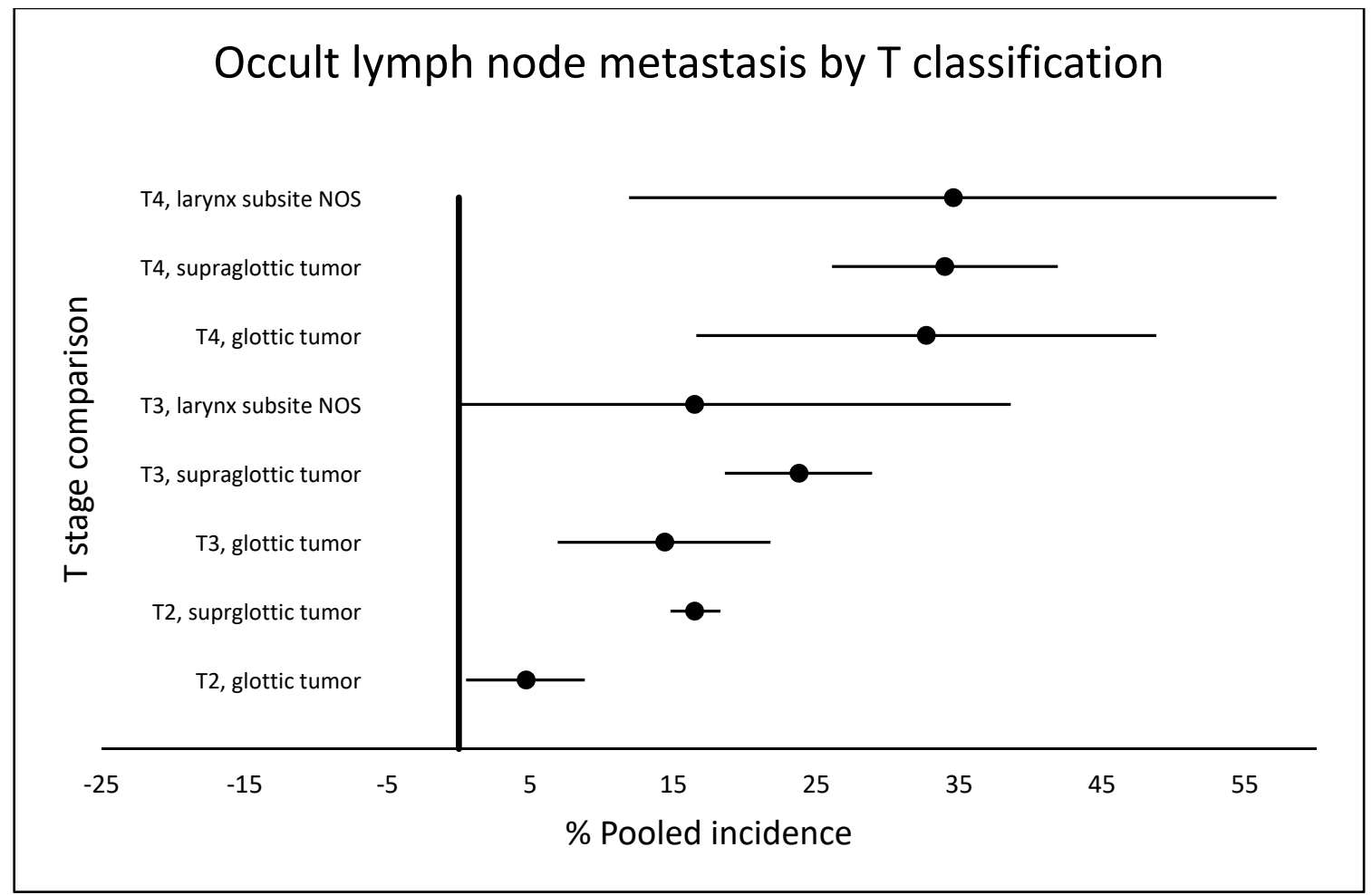

Figure 4. Comparison of pooled incidences of occult lymph node metastasis by T classification in cN0 larynx cancer. NOS: not otherwise specified.

\section{Discussion}

The role of elective neck treatment for larynx cancer patients with $\mathrm{cN} 0$ disease has been a subject of debate for many years [3,6,7]. This has been further complicated by the advent and effectiveness of non-surgical organ preservation protocols, as well as the introduction of endoscopic surgery as primary tumor treatment [5]. Moreover, since elective neck dissection may be a risk factor for pharyngocutaneous fistula after total laryngectomy, unnecessary neck dissection should be avoided [58]. The same holds true when radiotherapy is chosen as treatment, where extending the radiation fields unnecessarily can lead to serious complications that can adversely affect the quality of the patient's life [59]. Given these issues, the present study was undertaken in an attempt to provide more homogeneous data from the available literature by quantitating the incidence of occult nodal disease based on mucosal site and $\mathrm{T}$ classification. Furthermore, an attempt was made to subdivide the presence of nodal disease based on neck level in order to elucidate the application of the various types of selective neck dissections.

Lymphatic drainage patterns have been widely studied since the 1960s. The studies of Welsh et al. [60-62] demonstrated the differential drainage patterns of the larynx according to subsites. These studies demonstrate that the supraglottis is rich in lymphatic networks while for instance vocal cords do not have lymphatic vessels in their free margin. Liu et al. [63] demonstrated that the inferior surface of the vocal cord does have an important lymphatic network, with a similar drainage as the subglottis. These anatomical factors explain the pattern of distribution of lymph node metastasis, with levels II and III $[6,20,39]$ being the most frequently involved. Metastasis to level VI is not usually reported, except in specific studies on primary subglottic tumors or advanced tumors involving this area.

In this review, the evaluation of occult lymph node metastasis by subsite demonstrated a higher risk for supraglottic (19\%) compared to glottic tumors $(8 \%)$. However, there exists a wide variation in the reported results. Unfortunately, the most common clinical and histopathological characteristics of the primary tumor provided by the studies analyzed do not help to elucidate the cause of such 
heterogeneity. For example, for larynx tumors NOS, Deganello et al. [10] reported a low incidence of occult metastasis of $12 \%$ while Tsushima et al. [46], Xu et al. [40] and Candela et al. [13] reported incidences higher than $32 \%$. Heterogeneity was also found in supraglottic tumors. For example, Lawson et al. [36] found a 32.5\% incidence of occult metastasis while Tu et al. [19] found $8.3 \%$, but we are unable to explain these dramatic differences with the available data. Factors related to the indication for neck dissection, the policy of wait and see without providing the selection criteria used and the number of patients observed may explain these differences. Other factors responsible for this heterogeneity may be differences in diagnostic work-up and in the depth of histopathological examination of the neck dissection specimen. Routine histopathological examination of the neck dissection specimen can miss micrometastases in up to $15.2 \%$ and therefore the real incidence of occult metastases may be underestimated [64]. Serial sectioning and immunohistochemistry, as used in the examination of a sentinel lymph node biopsy, will detect micrometastases better, but is costly and can introduce a verification bias due to the higher number of sections. Finally, the use of more accurate diagnostic imaging techniques will result in lower reported incidence rates of occult metastases than the use of palpation only.

Analysis by T classification helps to reduce the variability among the patients studied and provides an improved understanding of the risk of occult nodal disease for each subsite. The assessment of occult lymph node metastases according to $\mathrm{T}$ classification confirms the increasing risk with increasing $\mathrm{T}$ stage. In fact, at the same $\mathrm{T}$ classification, supraglottic tumors always had a higher incidence in comparison to glottic tumors ( $16.5 \%$ vs. $4.7 \%$ in T2 tumors and $23.8 \%$ vs. $14.4 \%$ in T3 tumors). We found that early supraglottic tumors have a lower rate of occult metastasis than those with more advanced tumors. However, these differences were not significantly different. A remarkable result was found regarding glottic T3 tumors, which had a lower incidence than - T2 supraglottic tumors.

The data from this analysis support the notion that neck levels I and V are at low risk for occult nodal disease in patients with cN0 laryngeal cancer. For level I, the incidence derived from the pooled data from two studies is $2.4 \%$. However, it should be pointed out, as Candela et al. [13] state in their paper, that Level I is rarely involved and that the involvement they observe occurred usually in cases with neck node metastases in levels II, III or IV (75\% of the time). It should also be noted that Level I involvement in their study occurred in T3 or T4 primary tumors exhibiting histologic extra laryngeal spread. While these two studies did not provide information about sublevel (IA or IB) involvement, others suggest that the risk of involvement of sublevel IA in cN0 larynx tumors is insignificant [4]. Similarly, the rate of occult metastases in level V was only $0.4 \%$. Thus, routine elective treatment of these levels is not indicated in patients undergoing elective lymphadenectomy to remove potential occult disease among patients with laryngeal cancer and a cN0 neck. This recommendation is also supported by the results of a prospective trial that compared selective neck dissection of levels II to IV vs. modified radical neck dissection [65]. With regard to the inclusion of Level IV in elective treatment, our study found a very low rate of involvement of the nodes in this level in patients with supraglottic cancer, thus supporting the practice of not including them routinely in those cases. Similarly, our results regarding sublevel IIB indicated a $0.5 \%$ rate of occult disease supporting the practice of not including this sublevel routinely when performing a neck dissection for occult disease $[66,67]$. Some of these studies follow a uniform pattern regarding the lymphatic levels resected, while others use intraoperative findings or even frozen section results to guide the extent of the dissection. There is also still a lack of standardization in the nomenclature and in the execution of neck dissections, despite several initiatives to standardize them [68].

Even though there is a large number of publications dealing with the surgical treatment of the neck in larynx cancer, the quality of many studies is moderate, as shown in Figure 1. This is due, in part, to a selection bias of surgical studies, which may lead to a selection of more favorable primary tumors for surgery and those unfavorable for chemo/radiotherapy. Another factor is that most of these studies are retrospective case series, which are again prone to selection bias that can affect the pooled results. Other weaknesses are related to patient selection in individual studies. Furthermore, 
one study included a small number of patients with hypopharynx tumors, but the corresponding effect on the calculation of the pooled incidence is minimal [34]. Finally, during the more than 50-year period covered by our analysis, pre-therapeutic diagnostic procedures and protocols have changed dramatically, and thus the accuracy of the assessment of the neck stage prior to treatment.

Obviously, the few factors analyzed in this review (T classification and laryngeal subsite) are clearly insufficient to accurately predict the risk of lymph node metastasis. Other tumor features also have been reported to be relevant in the development of lymph node metastases, such as the infiltrating pattern of growth of the tumor, "tumor budding" and lymphovascular and perineural invasion [69-72]; molecular changes, such as loss of N33, STK11 and TP53 [73]; as well as immune alteration, such as HLA-E overexpression [74]. However, the means to assess these characteristics are not readily available in all institutions. Furthermore, most of these can only be evaluated after resection of the primary tumor, which precludes its clinical use to make decisions about elective neck dissection. The use of an SLN biopsy could be explored in some of these cases [5,36].

\section{Materials and Methods}

A search was conducted using the MESH and free-text terms "cancer", "larynx" and "neck dissection" in the PubMed, Embase and LILACS databases for studies published between 1966 and March 2019. An expanded search was conducted, and references were explored to identify additional articles. We did not restrict the publication language. All selected studies provided the rate of occult metastases in cN0 larynx squamous cell carcinoma patients primarily treated. All abstracts were reviewed by the authors. Those related with the subject were selected for further analysis. Those studies in which it was not possible to isolate specific data about larynx tumors were excluded. A differential analysis was made when studies did not report outcomes by subsites. The main outcome measure was the incidence of occult metastasis in neck dissection specimens based on the mucosal subsite, $\mathrm{T}$ classification and neck levels involved. Studies dealing with organ-preserving approaches were not included.

Data were collected based on sample size, patient characteristics and outcomes. Data from each study were extracted and recorded in an Excel spreadsheet. The unit of analysis was the study and statistical analysis was performed with Excel (Microsoft). The pooled incidence ( $95 \%$ confidence interval (CI)) was calculated for each outcome with random effects analysis because this method is a conservative summary estimate and incorporates between- and within-study variance [75]. For data with 0 events, a correction with 0.1 was made in order to obtain calculations. Studies that reported the frequency of occult metastases but did not discriminate it by subsite were classified as larynx tumors not otherwise specified (LNOS). The others were classified as having glottic and supraglottic tumors. The rate of positive nodes by neck level was calculated from the number of positive lymph nodes in each level divided by the total number of patients. Statistical heterogeneity was calculated with the Higgins I2 statistic. This represents the amount of variation in incidence of the included studies and when found it is recommended to look for an explanation based on the clinical factors, methods or analysis. Results of the intervention effects are presented with a forest plot graph.

Methodological quality of the included studies was evaluated with the Checklist for Case Series of the Joanna Briggs Institute Critical Appraisal tools for use in systematic reviews [76].

\section{Conclusions}

In summary, the incidence of occult lymph node metastasis in cN0 larynx cancer depends on the subsite and T classification, where supraglottic and T3-4 tumors have the higher percentages. The final recommendations for the patient with larynx cancer and a clinically negative neck are the following: For cN0 T1/2 glottic tumors, neck dissection is not recommended; for cN0 T1/2 supraglottic tumors, level I, level IV, level V and sublevel IIB should not be routinely included in the elective neck treatment; and for $\mathrm{cNO}$ T3/4 supraglottic tumors and cN0 T3/4 glottic tumors, level I, level V and sublevel IIB 
should not be routinely included in the elective neck treatment. This study did not allow us to make a recommendation about bilateral neck dissection in $\mathrm{cN} 0 \mathrm{~T} 1 / 2$ supraglottic tumors.

Supplementary Materials: The following are available online at http:/www.mdpi.com/2072-6694/12/4/1059/s1, Figure S1: Pooled incidence of occult lymph metastasis in larynx cancer by subsite, Figure S2: Pooled incidence of occult lymph metastasis in supraglottic larynx tumor, T1-2 stage, Figure S3: Pooled incidence of occult lymph metastasis in larynx cancer, subsite NOS (not otherwise specified), T3-4 stages, Figure S4: Pooled incidence of occult lymph metastasis by levels for larynx tumor, subsite NOS (not otherwise specified), Figure S5: Pooled incidence of occult lymph metastasis by levels for supraglottic tumor, Figure S6: Pooled incidence of occult lymph metastasis for glottic tumor by stage, Figure S7: Pooled incidence of occult lymph metastasis for supraglottic tumor by stage, Table S1: Data on involvement of lymph node levels by occult neck metastasis in cN0 larynx cancer.

Author Contributions: A.S., L.P.K.: Conceptualization, methodology, formal analysis, investigation, data curation, writing-original draft, writing-review and editing; J.P.S., J.E.M., K.D.O., K.T.R., C.E.S., J.P.R., C.S., A.C.-P., A.R.S., A.A.M., A.R., R.d.B., P.S., M.H., R.P.T., E.V.S., T.C., A.F.: Conceptualization, validation, writing-original draft, writing-review and editing, supervision. All authors have read and agreed to the published version of the manuscript.

Funding: This research received no external funding.

Conflicts of Interest: The authors declare no conflict of interest.

\section{References}

1. Karim-Kos, H.E.; de Vries, E.; Soerjomataram, I.; Lemmens, V.; Siesling, S.; Coebergh, J.W. Recent trends of cancer in Europe: A combined approach of incidence, survival and mortality for 17 cancer sites since the 1990s. Eur. J. Cancer 2008, 44, 1345-1389. [CrossRef] [PubMed]

2. Pagedar, N.A.; Kahl, A.R.; Tasche, K.K.; Seaman, A.T.; Christensen, A.J.; Howren, M.B.; Charlton, M.E. Incidence trends for upper aerodigestive tract cancers in rural United States counties. Head Neck 2019, 41, 2619-2624. [CrossRef] [PubMed]

3. Ferlito, A.; Buckley, J.G.; Shaha, A.R.; Silver, C.E.; Rinaldo, A.; Kowalski, L. The role of neck dissection in the treatment of supraglottic laryngeal cancer. Acta Otolaryngol. 2001, 121, 448-453. [CrossRef] [PubMed]

4. Ferlito, A.; Kowalski, L.P.; Silver, C.E.; Shaha, A.R.; Rinaldo, A.; Byers, R.M. The use and misuse of level IA dissection for head and neck cancer. Acta Otolaryngol. 2002, 122, 553-555. [CrossRef] [PubMed]

5. Ferlito, A.; Rinaldo, A. Controversies in the treatment of $\mathrm{N}(0)$ neck in laryngeal cancer: Neck dissection, no surgery or sentinel lymph node biopsy? ORL J. Otorhinolaryngol. Relat. Spec. 2000, 62, 287-289. [CrossRef] [PubMed]

6. Ferlito, A.; Silver, C.E.; Rinaldo, A. Selective neck dissection (IIA, III): A rational replacement for complete functional neck dissection in patients with N0 supraglottic and glottic squamous carcinoma. Laryngoscope 2008, 118, 676-679. [CrossRef]

7. Rinaldo, A.; Ferlito, A.; Kowalski, L.P.; Quer, M.; Suárez, C.; León, X.; Robbins, K.T. Is dissection of level V necessary in patients with $\mathrm{T}(2)-\mathrm{T}(4) \mathrm{N}(0)$ supraglottic cancer? J. Laryngol. Otol. 2004, 118, 175-178. [CrossRef]

8. Rodrigo, J.P.; Shah, J.P.; Silver, C.E.; Medina, J.E.; Takes, R.P.; Robbins, K.T.; Rinaldo, A.; Werner, J.A.; Ferlito, A. Management of the clinically negative neck in early-stage head and neck cancers after transoral resection. Head Neck 2011, 33, 1210-1219. [CrossRef]

9. Pantel, M.; Wittekindt, C.; Altendorf-Hofmann, A.; Boeger, D.; Buentzel, J.; Esser, D.; Mueller, A.; Wendt, T.G.; Guntinas-Lichius, O. Diversity of treatment of T2N0 glottic cancer of the larynx: Lessons to learn from epidemiological cancer registry data. Acta Otolaryngol. 2011, 131, 1205-1213. [CrossRef]

10. Deganello, A.; Gitti, G.; Meccariello, G.; Parrinello, G.; Mannelli, G.; Gallo, O. Effectiveness and pitfalls of elective neck dissection in N0 laryngeal cancer. Acta Otorhinolaryngol. Ital. 2011, 31, 216-221.

11. Flach, G.B.; Bloemena, E.; van Schie, A.; Hoekstra, O.S.; van Weert, S.; Leemans, C.R.; de Bree, R. Sentinel node identification in laryngeal cancer: Feasible in primary cancer with previously untreated neck. Oral Oncol. 2013, 49, 165-168. [CrossRef] [PubMed]

12. Levendag, P.; Vikram, B. The problem of neck relapse in early stage supraglottic cancer-results of different treatment modalities for the clinically negative neck. Int. J. Radiat. Oncol. Biol. Phys. 1987, 13, 1621-1624. [CrossRef]

13. Candela, F.C.; Shah, J.; Jaques, D.P.; Shah, J.P. Patterns of cervical node metastases from squamous carcinoma of the larynx. Arch. Otolaryngol. 1990, 116, 432-435. [CrossRef] [PubMed] 
14. Ramadan, H.H.; Allen, G.C. The influence of elective neck dissection on neck relapse in NO supraglottic carcinoma. Am. J. Otolaryngol. 1993, 14, 278-281. [CrossRef]

15. Kligerman, J.; Olivatto, L.O.; Lima, R.A.; Freitas, E.Q.; Soares, J.R.; Dias, F.L.; Melo, L.E.; Sa, G.M.; Duccini, E. Elective neck dissection in the treatment of T3/T4 N0 squamous cell carcinoma of the larynx. Am. J. Surg. 1995, 170, 436-439. [CrossRef]

16. Petrovic, Z.; Krejovic, B.; Janosevic, S. Occult metastases from supraglottic laryngeal carcinoma. Clin. Otolaryngol. Allied Sci. 1997, 22, 522-524. [CrossRef]

17. Yang, C.Y.; Andersen, P.E.; Everts, E.C.; Cohen, J.I. Nodal disease in purely glottic carcinoma: Is elective neck treatment worthwhile? Laryngoscope 1998, 108, 1006-1008. [CrossRef]

18. Güney, E.; Yigitbasi, O.G. Management of No neck in T1-T2 unilateral supraglottic cancer. Ann. Otol. Rhinol. Laryngol. 1999, 108, 998-1003. [CrossRef]

19. Tu, G.Y. Upper neck (level II) dissection for N0 neck supraglottic carcinoma. Laryngoscope 1999, 109, 467-470. [CrossRef]

20. León, X.; Quer, M.; Orús, C.; Sancho, F.J.; Bagué, S.; Burgués, J. Selective dissection of levels II-III with intraoperative control of the upper and middle jugular nodes: A therapeutic option for the N0 neck. Head Neck 2001, 23, 441-446. [CrossRef]

21. Elo, J.; Balatoni, Z.; Kotai, Z.; Bartfai, R. Considerations in the treatment of the node-negative (N0) neck in glottic carcinomas. Pathol. Oncol. Res. 2002, 8, 5. [CrossRef]

22. Amoros, L.; Carrasco, M.; Lopez, C.; Pla, A.; Ferrer, M.; Estelles, J.; Lopez, R. Tratamiento del cuello N0 en el cáncer supraglótico. Acta Otorrinolaringol. Esp. 2003, 54, 7.

23. Pinilla, M.; Gonzalez, F.M.; Lopez-Cortijo, C.; Arellano, B.; Herrero, J.; Trinidad, A.; Vergara, J. Management of N0 neck in laryngeal carcinoma. Impact on patient's survival. J. Laryngol. Otol. 2003, 117, 63-66. [CrossRef] [PubMed]

24. Spriano, G.; Piantanida, R.; Pellini, R.; Muscatello, L. Elective treatment of the neck in squamous cell carcinoma of the larynx: Clinical experience. Head Neck 2003, 25, 97-102. [CrossRef] [PubMed]

25. Coskun, H.H.; Erisen, L.; Basut, O. Selective neck dissection for clinically N0 neck in laryngeal cancer: Is dissection of level IIb necessary? Otolaryngol. Head Neck Surg. 2004, 131, 655-659. [CrossRef] [PubMed]

26. Khafif, A.; Fliss, D.M.; Gil, Z.; Medina, J.E. Routine inclusion of level IV in neck dissection for squamous cell carcinoma of the larynx: Is it justified? Head Neck 2004, 26, 309-312. [CrossRef] [PubMed]

27. Elsheikh, M.N.; Mahfouz, M.E.; Salim, E.I.; Elsheikh, E.A. Molecular assessment of neck dissections supports preserving level IIB lymph nodes in selective neck dissection for laryngeal squamous cell carcinoma with a clinically negative neck. ORL J. Otorhinolaryngol. Relat. Spec. 2006, 68, 177-184. [CrossRef] [PubMed]

28. Fiorella, R.; Di Nicola, V.; Fiorella, M.L.; Russo, C. “Conditional” neck dissection in management of laryngeal carcinoma. Acta Otorhinolaryngol. Ital. 2006, 26, 356-359.

29. Lim, Y.C.; Choi, E.C.; Lee, J.S.; Koo, B.S.; Song, M.H.; Shin, H.A. Is dissection of level IV absolutely necessary in elective lateral neck dissection for clinically N0 laryngeal carcinoma? Oral Oncol. 2006, 42, 102-107. [CrossRef]

30. Rodrigo, J.P.; Cabanillas, R.; Franco, V.; Suarez, C. Efficacy of routine bilateral neck dissection in the management of the N0 neck in T1-T2 unilateral supraglottic cancer. Head Neck 2006, 28, 534-539. [CrossRef]

31. Zhang, B.; Xu, Z.G.; Tang, P.Z. Elective lateral neck dissection for laryngeal cancer in the clinically negative neck. J. Surg. Oncol. 2006, 93, 464-467. [CrossRef] [PubMed]

32. Cağli, S.; Yüce, I.; Güney, E. Is routine inclusion of level IV necessary in neck dissection for clinically N0 supraglottic carcinoma? Otolaryngol. Head Neck Surg. 2007, 136, 287-290. [CrossRef] [PubMed]

33. Cağli, S.; Yüce, I.; Yiğitbaşi, O.G.; Güney, E. Is routine bilateral neck dissection absolutely necessary in the management of N0 neck in patients with supraglottic carcinoma? Eur. Arch. Otorhinolaryngol. 2007, 264, 1453-1457. [CrossRef] [PubMed]

34. Katilmis, H.; Ozturkcan, S.; Ozdemir, I.; Tuna, B.; Guvenc, I.A.; Ozkul, Y. Is dissection of levels 4 and 5 justified for cN0 laryngeal and hypopharyngeal cancer? Acta Otolaryngol. 2007, 127, 1202-1206. [CrossRef] [PubMed]

35. Yüce, I.; Cağli, S.; Bayram, A.; Güney, E. Occult metastases from T1-T2 supraglottic carcinoma: Role of primary tumor localization. Eur. Arch. Otorhinolaryngol. 2009, 266, 1301-1304. [CrossRef] [PubMed] 
36. Lawson, G.; Matar, N.; Nollevaux, M.C.; Jamart, J.; Krug, B.; Delos, M.; Remacle, M.; Borght, T.V. Reliability of sentinel node technique in the treatment of N0 supraglottic laryngeal cancer. Laryngoscope 2010, 120, 2213-2217. [CrossRef] [PubMed]

37. Mnejja, M.; Hammami, B.; Bougacha, L.; Chakroun, A.; Charfeddine, I.; Khabir, A.; Boudaoura, T.; Ghorbel, A. Occult lymph node metastasis in laryngeal squamous cell carcinoma: Therapeutic and prognostic impact. Eur. Ann. Otorhinolaryngol. Head Neck Dis. 2010, 127, 173-176. [CrossRef]

38. Csanady, M.; Czigner, J.; Vass, G.; Jori, J. Transoral CO2 laser management for selected supraglottic tumors and neck dissection. Eur. Arch. Otorhinolaryngol. 2011, 268, 1181-1186. [CrossRef]

39. Chone, C.T.; Kohler, H.F.; Magalhaes, R.; Navarro, M.; Altemani, A.; Crespo, A.N. Levels II and III neck dissection for larynx cancer with N0 neck. Braz. J. Otorhinolaryngol. 2012, 78, 59-63. [CrossRef]

40. Xu, Y.; Fei, M.; Wang, J.; Zheng, L.; Chen, Y.; Liu, Q. Clinical significance of micrometastases in lymph nodes from laryngeal squamous cell carcinoma. Am. J. Otolaryngol. 2012, 33, 402-407. [CrossRef]

41. Erdag, T.K.; Guneri, E.A.; Avincsal, O.; Sarioglu, S.; Ecevit, M.C.; Guneri, A.; Ikiz, A.O. Is elective neck dissection necessary for the surgical management of T2N0 glottic carcinoma? Auris Nasus Larynx 2013, 40, 85-88. [CrossRef] [PubMed]

42. Jia, S.; Wang, Y.; He, H.; Xiang, C. Incidence of level IIB lymph node metastasis in supraglottic laryngeal squamous cell carcinoma with clinically negative neck-a prospective study. Head Neck 2013, 35, 987-991. [CrossRef] [PubMed]

43. Furtado de Araújo Neto, V.J.; Cernea, C.R.; Aparecido Dedivitis, R.; Furtado de Araujo Filho, V.J.; Fabiano Palazzo, J.; Garcia Brandao, L. Cervical metastasis on level IV in laryngeal cancer. Acta Otorhinolaryngol. Ital. 2014, 34, 15-18. [PubMed]

44. Ma, H.; Lian, M.; Feng, L.; Li, P.; Hou, L.; Chen, X.; Huang, Z.; Fang, J. Factors contributing to lymph node occult metastasis in supraglottic laryngeal carcinoma cT2-T4 N0M0 and metastasis predictive equation. Chin. J. Cancer Res. 2014, 26, 7.

45. Djordjevic, V.; Bukurov, B.; Arsovic, N.; Dimitrijevic, M.; Jesic, S.; Nesic, V.; Petrovic, Z. Prospective case-control study of efficacy of bilateral selective neck dissection in primary surgical treatment of supraglottic laryngeal cancers with clinically negative cervical findings (N0). Clin. Otolaryngol. 2016, 41, 634-639. [CrossRef] [PubMed]

46. Tsushima, N.; Hayashi, R.; Shinozaki, T.; Tomioka, T.; Okano, W.; Ikeda, M. The role of elective neck dissection for cT4aN0 glottic squamous cell carcinoma. Jpn. J. Clin. Oncol. 2019, 49, 525-528. [CrossRef]

47. Bottcher, A.; Dommerich, S.; Sander, S.; Olze, H.; Stromberger, C.; Coordes, A.; Jowett, N.; Knopke, S. Nodal yield of neck dissections and influence on outcome in laryngectomized patients. Eur. Arch. Otorhinolaryngol. 2016, 273, 3321-3329. [CrossRef]

48. Dundar, R.; Aslan, H.; Ozbay, C.; Basoglu, S.; Guvenc, I.A.; Ogredik, E.A.; Ozturkcan, S.; Tayfun, M.A.; Katilmis, H. The necessity of dissection of level IIb in laryngeal squamous cell carcinoma: A clinical study. Otolaryngol. Head Neck Surg. 2012, 146, 390-394. [CrossRef]

49. Gross, B.C.; Olsen, S.M.; Lewis, J.E.; Kasperbauer, J.L.; Moore, E.J.; Olsen, K.D.; Price, D.L. Level IIB lymph node metastasis in laryngeal and hypopharyngeal squamous cell carcinoma: Single-institution case series and review of the literature. Laryngoscope 2013, 123, 3032-3036. [CrossRef]

50. Hicks, W.L., Jr.; Kollmorgen, D.R.; Kuriakose, M.A.; Orner, J.; Bakamjian, V.Y.; Winston, J.; Loree, T.R. Patterns of nodal metastasis and surgical management of the neck in supraglottic laryngeal carcinoma. Otolaryngol. Head Neck Surg. 1999, 121, 57-61. [CrossRef]

51. Koybasioglu, A.; Uslu, S.; Yilmaz, M.; Inal, E.; Ileri, F.; Asal, K. Lymphatic metastasis to the supraretrospinal recess in laryngeal squamous cell carcinoma. Ann. Otol. Rhinol. Laryngol. 2002, 111, 96-99. [CrossRef] [PubMed]

52. Lim, Y.C.; Lee, J.S.; Koo, B.S.; Choi, E.C. Level Ilb lymph node metastasis in laryngeal squamous cell carcinoma. Laryngoscope 2006, 116, 268-272. [CrossRef]

53. Redaelli de Zinis, L.O.; Nicolai, P.; Tomenzoli, D.; Ghizzardi, D.; Trimarchi, M.; Cappiello, J.; Peretti, G.; Antonelli, A.R. The distribution of lymph node metastases in supraglottic squamous cell carcinoma: Therapeutic implications. Head Neck 2002, 24, 913-920. [CrossRef] [PubMed]

54. Sezen, O.S.; Kubilay, U.; Haytoglu, S.; Unver, S. Frequency of metastases at the area of the supraretrospinal (level IIB) lymph node in laryngeal cancer. Head Neck 2007, 29, 1111-1114. [CrossRef] [PubMed] 
55. Villaret, A.B.; Piazza, C.; Peretti, G.; Calabrese, L.; Ansarin, M.; Chiesa, F.; Pellini, R.; Spriano, G.; Nicolai, P. Multicentric prospective study on the prevalence of sublevel Ilb metastases in head and neck cancer. Arch. Otolaryngol. Head Neck Surg. 2007, 133, 897-903. [CrossRef] [PubMed]

56. Wiegand, S.; Esters, J.; Muller, H.H.; Jacker, T.; Roessler, M.; Fasunla, J.A.; Werner, J.A.; Sesterhenn, A.M. Relevance of level I and IIB neck dissection in laryngeal cancer. J. Laryngol. Otol. 2012, 126, 795-799. [CrossRef] [PubMed]

57. Shen, C.X.; Li, Y.S.; Wang, Z.H.; Liu, C.; Lu, T.; Zeng, Q.; Wang, X.Q.; Zhu, J.; Cao, Y.D.; Hu, G.H. Characteristics of cervical lymph node metastasis of cN0 laryngeal carcinoma. Chin. J. Otorhinolaryngol. Head Neck Surg. 2019, 54, 343-348. [CrossRef]

58. Lansaat, L.; van der Noort, V.; Bernard, S.E.; Eerenstein, S.E.J.; Plaat, B.E.C.; Langeveld, T.; Lacko, M.; Hilgers, F.J.M.; de Bree, R.; Takes, R.P.; et al. Predictive factors for pharyngocutaneous fistulization after total laryngectomy: A Dutch Head and Neck Society audit. Eur. Arch. Otorhinolaryngol. 2018, 275, 783-794. [CrossRef]

59. Strojan, P.; Hutcheson, K.A.; Eisbruch, A.; Beitler, J.J.; Langendijk, J.A.; Lee, A.W.M.; Corry, J.; Mendenhall, W.M.; Smee, R.; Rinaldo, A.; et al. Treatment of late sequelae after radiotherapy for head and neck cancer. Cancer Treat. Rev. 2017, 59, 79-92. [CrossRef]

60. Welsh, L.W. The normal human laryngeal lymphatics. Ann. Otol. Rhinol. Laryngol. 1964, 73, 569-582. [CrossRef]

61. Welsh, L.W.; Welsh, J.J. Laryngeal lymphatics, human in vivo studies. Trans. Am. Acad. Ophthalmol. Otolaryngol. 1963, 67, 524-529. [PubMed]

62. Welsh, L.W.; Welsh, J.J.; Rizzo, T.A., Jr. Laryngeal spaces and lymphatics: Current anatomic concepts. Ann. Otol. Rhinol. Laryngol. Suppl. 1983, 105, 19-31. [CrossRef] [PubMed]

63. Liu, Y.H.; Xu, S.C.; Tu, L.L.; Zhang, K.L.; Lu, D.H.; Zhang, M. A rich lymphatic network exists in the inferior surface of the vocal cord. Surg. Radiol. Anat. 2006, 28, 125-128. [CrossRef] [PubMed]

64. Rinaldo, A.; Devaney, K.O.; Ferlito, A. Immunohistochemical studies in the identification of lymph node micrometastases in patients with squamous cell carcinoma of the head and neck. ORL J. Otorhinolaryngol. Relat. Spec. 2004, 66, 38-41. [CrossRef] [PubMed]

65. Brazilian Head and Neck Cancer Study Group. End results of a prospective trial on elective lateral neck dissection vs. type III modified radical neck dissection in the management of supraglottic and transglottic carcinomas. Head Neck 1999, 21, 694-702. [CrossRef]

66. Ferlito, A.; Silver, C.E.; Suarez, C.; Rinaldo, A. Preliminary multi-institutional prospective pathologic and molecular studies support preservation of sublevel IIB and level IV for laryngeal squamous carcinoma with clinically negative neck. Eur. Arch. Otorhinolaryngol. 2007, 264, 111-114; discussion 109. [CrossRef]

67. Rinaldo, A.; Elsheikh, M.N.; Ferlito, A.; Chone, C.T.; Coskun, H.H.; Koybasioglu, A.; Esclamado, R.M.; Corlette, T.H.; Talmi, Y.P. Prospective studies of neck dissection specimens support preservation of sublevel IIB for laryngeal squamous carcinoma with clinically negative neck. J. Am. Coll. Surg. 2006, 202, 967-970. [CrossRef]

68. Ferlito, A.; Robbins, K.T.; Shah, J.P.; Medina, J.E.; Silver, C.E.; Al-Tamimi, S.; Fagan, J.J.; Paleri, V.; Takes, R.P.; Bradford, C.R.; et al. Proposal for a rational classification of neck dissections. Head Neck 2011, 33, 445-450. [CrossRef]

69. Antonelli, A.R.; Nicolai, P.; Cappiello, J.; Peretti, G.; Molinari Tosatti, M.P.; Rosa, D.; Grigolato, P.G.; Favret, M.; Maroccolo, D. Basement membrane components in normal, dysplastic, neoplastic laryngeal tissue and metastatic lymph nodes. Acta Otolaryngol. 1991, 111, 437-443. [CrossRef]

70. Ozdek, A.; Sarac, S.; Akyol, M.U.; Unal, O.F.; Sungur, A. Histopathological predictors of occult lymph node metastases in supraglottic squamous cell carcinomas. Eur. Arch. Otorhinolaryngol. 2000, 257, 389-392. [CrossRef]

71. Kaur, K.; Sonkhya, N.; Bapna, A.S. Nodal metastases from laryngeal carcinoma and their correlation with certain characteristics of the primary tumor. Indian J. Otolaryngol. Head Neck Surg. 2002, 54, 255-263. [CrossRef] [PubMed]

72. Makitie, A.A.; Almangush, A.; Rodrigo, J.P.; Ferlito, A.; Leivo, I. Hallmarks of cancer: Tumor budding as a sign of invasion and metastasis in head and neck cancer. Head Neck 2019, 41, 3712-3718. [CrossRef] [PubMed] 
73. van Hooff, S.R.; Leusink, F.K.; Roepman, P.; Baatenburg de Jong, R.J.; Speel, E.J.; van den Brekel, M.W.; van Velthuysen, M.L.; van Diest, P.J.; van Es, R.J.; Merkx, M.A.; et al. Validation of a gene expression signature for assessment of lymph node metastasis in oral squamous cell carcinoma. J. Clin. Oncol. 2012, 30, 4104-4110. [CrossRef] [PubMed]

74. Silva, T.G.; Crispim, J.C.; Miranda, F.A.; Hassumi, M.K.; de Mello, J.M.; Simoes, R.T.; Souto, F.; Soares, E.G.; Donadi, E.A.; Soares, C.P. Expression of the nonclassical HLA-G and HLA-E molecules in laryngeal lesions as biomarkers of tumor invasiveness. Histol. Histopathol. 2011, 26, 1487-1497. [CrossRef] [PubMed]

75. Neyeloff, J.L.; Fuchs, S.C.; Moreira, L.B. Meta-analyses and Forest plots using a microsoft excel spreadsheet: Step-by-step guide focusing on descriptive data analysis. BMC Res. Notes 2012, 5, 52. [CrossRef] [PubMed]

76. Moola, S.; Munn, Z.; Tufanaru, C.; Aromataris, E.; Sears, K.; Sfetcu, R.; Currie, M.; Qureshi, R.; Mattis, P.; Lisy, K.; et al. Systematic reviews of etiology and risk. In Joanna Briggs Institute Reviewer's Manual; Aromataris, E., Munn, Z., Eds.; The Joanna Briggs Institute: Adelaide, Australia, 2017.

(C) 2020 by the authors. Licensee MDPI, Basel, Switzerland. This article is an open access article distributed under the terms and conditions of the Creative Commons Attribution (CC BY) license (http://creativecommons.org/licenses/by/4.0/). 